\title{
TRIJU巳 SKIRTINGŲ KINEZITERAPIJOS PROGRAMŲ EFEKTYVUMAS GERINANT KAKLINĖS STUBURO DALIES SKAUSMU BESISKUNDŽIANČIŲJŲ GYVENIMO KOKYBĘ
}

\section{Evelina Ašmontaitė, Vilma Dudonienė}

Lietuvos sporto universitetas

\section{SANTRAUKA}

Tyrimo pagrindimas. Kaklo skausmas yra globalus sveikatos sutrikimas, labai paveikiantis asmens gyvenimo kokybę. Dèl skirtingai vertinamų metodikų pasigendama vieningos tyrejų nuomonès, kokia kineziterapijos metodika yra efektyviausia mažinant kaklinės stuburo dalies skausmą, todèl pasirinkome palyginti tris skirtingas intervencijas.

Tikslas - išanalizuoti skirtingų kineziterapijos metodikų poveikị tiriamujų gyvenimo kokybei, esant kaklinès stuburo dalies skausmui.

Metodai. Buvo tiriami 55 asmenys, besiskundžiantys nespecifinio pobūdžio lètiniu kaklo skausmu. Tiriamieji buvo suskirstyti į keturias grupes: pirma $(n=15)$ - jiems iš pradžių taikytas kaklo ir pečių lanko masažas, paskui - kaklo ir pečių lanko tempimo ir stiprinimo pratimai (masažas ir pratimai); antra $(\mathrm{n}=15)$ - taikyti kaklo ir pečių lanko tempimo ir stiprinimo pratimai, paskui - kaklo ir pečių lanko masažas (pratimai ir masažas); trečia $(\mathrm{n}=13)$ - taikytas tik kineziterapinis pleistras (KIN pleistras); ketvirta $(\mathrm{n}=12)$ - kontrolinè grupè, kuriai netaikoma jokia intervencija. Prieš intervencijas ir po jų buvo įvertinta tiriamujų gyvenimo kokybė kaklo negalios indeksu (KNI), miego kokybė - Pitsburgo miego kokybės indeksu, taip pat buvo ịvertintas nuovargis.

Rezultatai. Visose grupèse, lyginant su kontroline, statistiškai reikšmingai sumažèjo kaklo negalios indekso (KNI) reikšmès, nuovargis, pagerèjo miego kokybė.

Išvados. 1. Tiriamujų , kuriems taikytas masažas, paskui - gydomieji pratimai, gyvenimo kokybė reikšmingai pagerèjo. 2. Tiriamujų, kuriems taikyti gydomieji pratimai, paskui - masažas, gyvenimo kokybė taip pat reikšmingai pagerèjo. 3. Tiriamujų, kuriems taikytas kineziterapinis pleistras, gyvenimo kokybè reikšmingai pagerèjo.

Raktažodžiai: kaklo skausmas, masažas, kineziterapinis pleistras, pratimai, gyvenimo kokybè.

\section{IVADAS}

Kaklo skausmas yra globalus sveikatos sutrikimas, labai paveikiantis asmens gyvenimo kokybę (Lee et al., 2013). Pagal paplitimą kaklo skausmas yra trečia pagrindinè patiriamo skausmo priežastis po galvos ir juosmeninès nugaros dalies skausmo (Lee et al., 2013). Dažnai kaklo skausmo priežastis nustatyti yra sunku, visgi manoma, kad jis gali būti susijęs su degeneraciniais procesais (Liu et al., 2017). Atlikti tyrimai rodo, kad kaklinès stuburo dalies skausmas dažnai patiriamas nesulaukus pilnametystès (Lee et al., 2013; Liu et al., 2017), o kaklo skausmo riziką labiau padidina mažas fizinis aktyvumas ir sėslus gyvenimo būdas (Cheung et al., 2013).

Kaklo skausmas neigiamai veikia žmogaus gyvenimo kokybę dar ir dèl to, kad mažèja asmens darbingumo lygis, dèl to didèja sveikatos sistemos išlaidos, finan- 
sinè našta gyventojams. Ši problema ypač aktuali išsivysčiusiose šalyse, taip pat ir Lietuvoje. Didejja žmonių, dirbančių pasyvų sėdimą darbą, skaičius, todèl svarbu daug dèmesio skirti kaklo skausmo profilaktikos užtikrinimui ir gydymui (Uluğ et al., 2016).

Kineziterapijos metodų pasirinkimas yra labai platus, bet nepakanka ịrodymų, kuris gydymo modelis efektyviausias (Costello, 2018). Lietuvos ir užsienio mokslininkų tyrimuose plačiai nagrinëjamos konkrečios gydymo metodikos, taikomos esant kaklinès stuburo dalies skausmui, tačiau pasigendama tarpusavyje derinamu priemonių efektyvumo vertinimo. Dažniausiai masažas atliekamas atskirai, tačiau jis vertinamas kaip labai svarbi kineziterapinès procedūros dalis. Teigiama, kad norint visapusiškai padèti ligoniui reikia masažą ir pratimus sujungti ị vieną procedūrą (Delgado et al., 2010), todèl savo tyrime pasirinkome šias priemones derinti kartu. Kai kurie mokslininkai teigia, kad efektyviau masažą atlikti prieš gydomuosius pratimus, nes tuomet padidejja ligonio mobilumas, bet tai turi ir neigiamą poveikị. Sudirginus raumenis gali atsirasti skausmas, kuris vèliau riboja atliekamus judesius mankštos metu (Fanavoll et al., 2016). Tyrimo metu analizavome abu variantus - kai masažas buvo taikomas prieš aktyvius gydomuosius pratimus ir po jų.

Autoriai, tyrę kineziterapinio pleistro poveikị (Dawood et al., 2013) kaklinès stuburo dalies skausmo mažinimui, teigia, kad kineziterapinis pleistras sumažina kaklo skausmą, tačiau pastebimas tik trumpalaikis 24 valandų efektas. Dèl skirtingai vertinamų metodikų pasigendama vieningos tyrejų nuomonès, kokia kineziterapijos metodika yra pati efektyviausia mažinant kaklinès stuburo dalies skausmą.

Mūsų tyrimo tikslas - išanalizuoti skirtingų kineziterapijos programų poveikị tiriamujų gyvenimo kokybei, esant kaklinès stuburo dalies skausmui.

\section{METODAI}

Tyrimo organizavimas. Tyrimas atliktas Lietuvos sporto universitete $2018 \mathrm{~m}$. rugsejjo-2019 m. sausio mėnesiais, gavus Lietuvos sporto universiteto Biomedicinos etikos komiteto leidimą (NR. BEK-KIN(M)-2018-45).

Pradedant tiriamujų paiešką socialiniuose tinkluose, buvo parašytas skelbimas, kviečiantis dalyvauti šiame tyrime. I skelbimą atsiliepe 68 savanoriai. Visi tiriamieji turejo atitikti tam tikrus atrankos kriterijus.

Tiriamujų ịtraukimo ị tyrimą kriterijai:

- kaklo skausmo trukmè > 3 mèn.;

- skausmas pagal SAS 3-6 balai;

- darbingas amžius (18-25 m.);

- nèra neurologinių patologijų; 
- Baeck'io kasdienio fizinio aktyvumo klausimyno atsakymais surinkta 7-10 balu;

- neigiamas žasto atitraukimo testas;

- neigiamas kaklo kompresijos testas;

- neigiamas Jackson'o kompresijos testas.

Atmetimo kriterijai:

- nëštumas;

- struktūrinès deformacijos kaklinèje stuburo dalyje;

- kitos ligos ūmi stadija, uždegimas,

- atlikta stuburo operacija;

- odos pažeidimai;

- alergija kineziterapinio pleistro juostelèms;

- nesutikimas dalyvauti tyrime.

Po atmetimo ir ịtraukimo ị tyrimą kriterijų suformuota 55 tiriamujų, sutikusių savanoriškai dalyvauti tyrime, grupè.

Tyrimo eiga. Asmenys, sutikę dalyvauti tyrime, išsitraukẻ lapelį su skaičiumi $1,2,3$ arba 4, ir pagal tai buvo priskirti atitinkamai grupei.

Pirmą tiriamujų grupę $(n=15)$ sudarė asmenys, kuriems procedūros pradžioje taikytas kaklo ir pečių lanko masažas, paskui - kaklo ir pečių lanko tempimo ir stiprinimo pratimai (masažas + pratimai). Antrą $(n=15)$ - asmenys, kuriems taikyti kaklo ir pečių lanko tempimo ir stiprinimo pratimai, paskui - kaklo ir pečiu lanko masažas (pratimai + masažas). Trečią $(\mathrm{n}=13)$-asmenys, kuriems taikytas kineziterapinis pleistras (KIN pleistras). Ketvirtą $(\mathrm{n}=12)$ - asmenys, kuriems nebuvo taikoma jokia kineziterapinè intervencija, bet paprašyta, kad per tyrimo laikotarpị kardinaliai nekeistų savo gyvenimo būdo (kontrolinè).

1 lentelè. Tiriamųjų charakteristikos

\begin{tabular}{|c|c|c|c|c|}
\hline Grupė & $\begin{array}{c}\text { Tiriamųjų } \\
\text { amžius } \\
(\mathbf{m} \pm \mathrm{SN})\end{array}$ & $\begin{array}{c}\overline{\text { Ūgis }} \\
(\mathrm{cm} \pm \mathrm{SN})\end{array}$ & $\begin{array}{c}\text { Svoris } \\
(\mathbf{k g} \pm \mathrm{SN})\end{array}$ & $\begin{array}{c}\text { KMI } \\
\text { (masè }(\mathbf{k g}) / \\
(\bar{u} g i s(\mathbf{m}))^{2} \\
\pm \mathbf{s n}\end{array}$ \\
\hline $\begin{array}{l}\text { Masažas ir pratimai } \\
(\mathrm{n}=15 / \mathrm{V}=7 / \mathrm{M}=8)\end{array}$ & $22,93 \pm 1,66$ & $171,20 \pm 9,15$ & $60,60 \pm 13,77$ & $20,32 \pm 2,78$ \\
\hline $\begin{array}{l}\text { Pratimai ir masažas } \\
(\mathrm{n}=15 / \mathrm{V}=8 / \mathrm{M}=7)\end{array}$ & $23,40 \pm 1,35$ & $173,73 \pm 8,51$ & $65,60 \pm 13,42$ & $21,55 \pm 2,71$ \\
\hline $\begin{array}{l}\text { KIN pleistras } \\
(\mathrm{n}=13 / \mathrm{V}=7 / \mathrm{M}=6)\end{array}$ & $23,53 \pm 1,22$ & $172,15 \pm 7,45$ & $63,60 \pm 11,67$ & $20,35 \pm 2,11$ \\
\hline $\begin{array}{l}\text { Kontroliné } \\
(\mathrm{n}=12 / \mathrm{V}=6 / \mathrm{M}=6)\end{array}$ & $22,08 \pm 1,34$ & $171,56 \pm 6,09$ & $64,60 \pm 10,44$ & $21,67 \pm 1,75$ \\
\hline
\end{tabular}

Pastaba. V - vyrai; M - moterys; KMI - kūno masès indeksas. 
Trijų skirtingų kineziterapijos programų efektyvumas gerinant kaklinės stuburo dalies skausmu besiskundžiančiųu gyvenimo kokybę

Tiriamujų amžius, ūgis, svoris ir kūno masės indeksas (KMI) grupèse statistiškai reikšmingai nesiskyrè.

Grupėse, kuriose gydomieji pratimai buvo derinami su masažu, gydomuosius pratimus tiriamieji atliko iš sẻdimų ir stovimų pradinių paděčį. Raumenų tempimo pratimai buvo atliekami izometriškai išlaikant ịtempimą nuo 5 iki $15 \mathrm{~s}$. Tempimo pratimai - $15 \mathrm{~min}$, stiprinimo pratimai - $15 \mathrm{~min}$, atsipalaidavimo pratimai 5 min. Kaklo ir pečių lanko 35 minučių masažą atliko kineziterapeutas, ligoniui gulint ant masažinio stalo. Šių grupių tiriamiesiems buvo skirta po 10 grupinių fizinių užsièmimų ir individualių masažo procedūrų pagal atitinkamai grupei priskirtą procedūrų seką. 10 užsièmimų vyko keturias savaites (pirmą ir trečią savaitę tiriamieji lankèsi po tris kartus, antrą ir ketvirtą - po du kartus).

Kineziterapinio pleistro grupès tiriamieji kas antrą savaitę turèjo apsilankyti pas kineziterapeutą, kad būtų užklijuojamos juostelès. Pleistro klijavimui buvo pasirinkta raumeninè krypties (korekcinė) technika. Kineziterapinis pleistras buvo klijuojamas kas antrą savaitę. Buvo paprašyta, kad asmuo po 4-6 dienų nusiplëštų juostelę, o laikotarpiu iki kito pleistro klijavimo neatlikinètų papildomų fizinių pratimų. Naudojama buvo viena $5 \mathrm{~cm}$ pločio $\mathrm{V}$ formos juostelè - tokio ilgio, kad eitu abipus kaklinės stuburo dalies nuo menčių viršaus iki plaukuotosios galvos dalies, ir dvi $10 \mathrm{~cm}$ ilgio ir $2 \mathrm{~cm}$ pločio juostelès, klijuojamos ant viršaus $\mathrm{V}$ formos juostelès - viena ties menčių viršutine dalimi, kita lygiagrečiai centimetru žemiau.

Kontrolinès grupès tiriamieji tyrimą turèjo pakartoti po 4 savaičių, šiuo laikotarpiu grupès tiriamieji buvo paprašyti kardinaliai nekeisti savo gyvenimo būdo.

Visi tiriamieji, patekę ị tam tikrą grupę, žinojo, kokios metodikos taikomos ir kitose grupėse.

Tyrimo pradžioje buvo testuojamos visų grupių tiriamujų aktyvių galvos judesių amplitudès, vertinami šie galvos judesiai: lenkimas, tiesimas, šoninis lenkimas i kairę ir i dešinę, sukimas ị kairę ir i dešinę; giliujų kaklo raumenų ištverme ir jèga bei vertinamas fizinis aktyvumas; funkcinè negalia; nuovargis, miego kokybè. Pakartotinai tiriamieji ištirti praẻjus 4 savaitèms.

\section{Ištyrimo metodai}

Skausmo vertinimas. Tyrimo pradžioje, naudojant skaitinès analogijos skausmo skalę, tiriamujų buvo prašoma ịvertinti jaučiamo skausmo intensyvumą. Vertinamas didžiausias skausmas, jaučiamas kaklo ir pečių lanko srityje per paskutiniąsias 24 valandas (Pasero, 1999).

Žasto atitraukimo testas. Testas naudojamas kaklinès stuburo dalies radikulopatijai ištirti. Testo metu sėdinčio asmens prašoma pakaitomis vieną, paskui kitą ranką padèti ant viršugalvio. Ranka ant galvos turi būti išlaikoma 5-10 s. Testas teigiamas, kai kaklo skausmas laikant ranką ant galvos dingsta, neigiamas - kai skausmas išlieka (Konin, 2006). 
Jackson'o kompresijos testas. Testas naudojamas kaklinès stuburo dalies pažeidimams ar neurologinėms patologijoms nustatyti. Testo metu ligonis sėdėdamas pasuka galvą i vieną pusę, o kineziterapeutas atsargiai paspaudžia galvą žemyn, tas pat daroma pasukus galvą i kitą pusę. Testas vertinamas teigiamai, kai padideja lokalizuotas arba periferinis skausmas. Testas vertinamas neigiamai, kai skausmas neišprovokuojamas (Konin, 2006).

\section{Tyrimo metodai, naudoti vertinant gyvenimo kokybę}

Fizinio aktyvumo vertinimas. Jis vertinamas naudojant Baeck'io kasdienio fizinio aktyvumo klausimyną (angl. Baecke Physical Activity Questionnaire). Klausimyną sudaro 16 klausimų, kurie suskirstyti ị sportinès, darbinès veiklos ir laisvalaikio sritis. Kiekvienoje dalyje yra keletas klausimų, kuriuos sudaro 5 atsakymo variantai (niekada / retai / kartais / dažnai / visada) (Baecke et al., 1982).

Kaklo funkcines negalios vertinimas. Tiriamuju prašoma atsakyti i 10 klausimų, 7 iš jų susiję su kasdiene tiriamojo veikla, 2 - su jaučiamu skausmu ir 1 klausimas susijęs su gebejimu sutelkti dèmesị. Kiekvienas klausimas turi 5 atsakymo variantus. Variantai vertinami balais nuo 0 iki 5. Skaičiuojama bendra balų suma kuo didesnis balas, tuo didesnè funkcinè negalia (Vernon, Mior, 1991).

Miego kokybes vertinimas. Miego kokybei vertinti naudotas Pitsburgo miego kokybės indekso (PMKI) klausimynas (Buysse et al., 1989). PMKI sudaro septynios skalès: subjektyvios miego kokybès, užmigimo laiko, miego trukmès, ịprasto miego efektyvumo, prabudimų, medikamentų vartojimo. Pagal pateiktus klausimus tiriamasis pats įvertina savo miegą pagal keturias gradacijas - nuo 0 (kai nèra jokių sutrikimų) iki 3 balų (kai miego sutrikimai dideli) (Varoneckas, 2003).

Nuovargio vertinimo testas. Šio testo tikslas - išsiaiškinti žmogaus savijautą pastaruoju metu. Testą sudaro 20 teiginių - kuo labiau sutinkama su teiginiu, žymimas langelis arčiau sakinio „Taip, tai tiesa“, ir atvirkščiai, kuo labiau nesutinkama su teiginiu - tuo arčiau sakinio „Ne, tai netiesa“. Atsakymų balai verčiami procentais ir apskaičiuojami pagal specialią formulę. Kuo suma artimesnè 100 procentu, tuo didesnis negalavimas (Stankus, 2007).

Duomenų apdorojimo statistiniai metodai. Tyrimo duomenys apdoroti naudojant matematinės statistikos metodų „IBM SPSS 20.0“ programą, grafinis rezultatu vaizdavimas atliktas „MS Excel 2017“ programa. Rezultatu patikimumui vertinti ir hipotezėms tikrinti buvo naudojama aprašomoji statistika bei neparametriniai kriterijai. Pasirinktas reikšmingumo lygmuo - 0,05. Hipotezei apie kintamojo skirstinio normalumą tikrinti buvo naudotas Shapyr'o-Vilk'o testas. Vidurkių skirtumų statistinis reikšmingumas nepriklausomoms imtims, kai duomenys pasiskirstę pagal normaluji skirstini, vertinamas vadovaujantis Studen'to $t$ testu, o priklausomoms imtims - poriniu Student'o $t$ testu. Duomenys nepriklausomoms imtims, kai nèra normaliojo kintamujų pasiskirstymo, vertinami vadovaujantis 
Mann'o-Whitney'aus kriterijumi, o priklausomoms imtims - Wilkcoxon'o kriterijumi. Rezultatuose duomenys pateikiami kaip aritmetiniai vidurkiai () ir standartiniai nuokrypiai (SD).

\section{TYRIMO REZULTATAI}

Kaklo negalios indeksas. Iৃvertinus tiriamųjų kaklo negalios indeksą nustatyta, kad visų grupių tiriamujjų indekso vidurkiai prieš intervencijas statistiškai reikšmingai nesiskyrè $(\mathrm{p}>0,05)$. Atlikus pakartotinị kaklo negalios indekso vertinimą nustatyta, kad tiriamujjų būklè reikšmingai pagerèjo ir kaklo negalios indekso vidurkiai reikšmingai sumažejo ir ypač tose grupèse, kuriose masažas buvo derinamas su fiziniais pratimais (2 lent.).

2 lentelè. Kaklo negalios indeksas prieš skirtingas intervencijas ir po jụ

\begin{tabular}{|l|c|c|}
\hline \multirow{2}{*}{ Grupé } & \multicolumn{2}{|c|}{ Kaklo negalios indeksas } \\
\cline { 2 - 3 } & Prieš (balai) & Po (balai) \\
\hline Masažas ir pratimai & $9,51 \pm 1,71$ & $3,53 \pm 2,26^{*}$ \\
\hline Pratimai ir masažas & $9,70 \pm 2,9$ & $5,10 \pm 2,75^{*}$ \\
\hline KIN pleistras & $10,06 \pm 1,27$ & $8,40 \pm 1,14 *$ \\
\hline Kontroliné & $10,00 \pm 1,25$ & $9,40 \pm 1,59$ \\
\hline
\end{tabular}

Pastaba. ${ }^{*}-\mathrm{p}<0,05$, lyginant vidurkius grupèse prieš procedūras ir po jų.

Miego kokybė. İvertinus miego kokybę prieš intervencijas nustatyta, kad miego kokybės indekso vidurkiai tarp grupių prieš tyrimą statistiškai reikšmingai nesiskyrè $(\mathrm{p}>0,05)$. Visų grupių tiriamųjų surinktų balų suma pateko ị intervalą $10<$ PMKI $\leq 15$, tai reiškia vidutinius miego sutrikimus. Visgi pakartotinio ištyrimo metu po intervencijų taikymo nustatyta, kad miego kokybė reikšmingai pagerèjo tiriamosiose grupėse, kuriose masažas buvo derinamas su fiziniais pratimais (3 lent.).

3 lentelè. Pitsburgo miego kokybės indeksas prieš skirtingas intervencijas ir po jų

\begin{tabular}{|l|c|c|}
\hline \multirow{2}{*}{ Grupė } & \multicolumn{2}{|c|}{ Pitsburgo miego kokybės indeksas } \\
\cline { 2 - 3 } & Prieš (balai) & Po (balai) \\
\hline Masažas ir pratimai & $11,80 \pm 5,46$ & $1,2 \pm 1,2 *$ \\
\hline Pratimai ir masažas & $11,12 \pm 5,34$ & $2,53 \pm 1,57 *$ \\
\hline KIN pleistras & $10,80 \pm 1,26$ & $6,4 \pm 1,06 *$ \\
\hline Kontroline & $11,78 \pm 1,09$ & $10,60 \pm 1,05$ \\
\hline
\end{tabular}

Pastaba. * $-\mathrm{p}<0,05$, lyginant vidurkius grupèse prieš procedūras ir po jų. 
Nuovargio vertinimas. Kuo nuovargio vertinimo vidurkis artimesnis šimtui procentų, tuo asmens negalavimas didesnis. İvertinus bendrą nuovargi prieš intervencijas nustatyta, kad bendro nuovargio vidurkiai tarp grupių prieš tyrimą statistiškai reikšmingai nesiskyrè $(p>0,05)$. Lyginant bendro nuovargio testo rezultatus grupèse gauta, kad labiausiai bendrasis nuovargis statistiškai reikšmingai sumažèjo tose grupèse, kuriose masažas buvo derinamas su fiziniais pratimais (4 lent.).

4 lentelè. Nuovargio vertinimo rodiklių kitimo duomenys grupèse

\begin{tabular}{|l|c|c|}
\hline \multirow{2}{*}{ Grupė } & \multicolumn{2}{|c|}{ Nuovargio vertinimas } \\
\cline { 2 - 3 } & Priěs (\%) & Po (\%) \\
\hline Masažas ir pratimai & $48,67 \pm 11,87$ & $16,67 \pm 9,57 *$ \\
\hline Pratimai ir masažas & $49,43 \pm 10,67$ & $17,87 \pm 10,55 *$ \\
\hline KIN pleistras & $46,73 \pm 1,70$ & $26,73 \pm 1,70 *$ \\
\hline Kontroline & $48,80 \pm 1,37$ & $47,80 \pm 1,30$ \\
\hline
\end{tabular}

Pastaba. * $-\mathrm{p}<0,05$, lyginant vidurkius grupèse prieš procedūras ir po jų.

\section{REZULTATŲ APTARIMAS}

Mūsų tyrimo tikslas buvo palyginti fizinių pratimų, derinamų su masažu ir kineziterapiniu pleistru, poveikị tiriamujų gyvenimo kokybei, esant kaklinės stuburo dalies skausmui.

Tirtų asmenų, besiskundžiančių kaklo skausmais, amžiaus vidurkis buvo $22,93 \pm 1,66$ m. Visgi mokslininkai (Childs et al., 2018) savo tyrime nurodo, kad dažniau lètiniai kaklo skausmai kankina 40 metų ir vyresnius asmenis, 30-mečiai ir jaunesni kur kas rečiau skundžiasi šiuo skausmu.

Mūsų tirtų vyrų ir moterų pasiskirstymas grupèse pagal lytị buvo panašus. Kai kurie tyrejjai (Cagnie et al., 2017) teigia, kad moterys turi beveik dvigubai didesnę kaklo skausmų riziką nei vyrai, o kiti (Blozik et al., 2009) - kad beveik 80\% jų tiriamujjų buvo moterys.

Mes nustatėme, kad visų tiriamų grupių gyvenimo kokybė, vertinta kaklo negalios indeksu, po intervencijų reikšmingai pagerèjo, o kontrolinėje grupèje reikšmingų pokyčių nenustatyta. Mokslininkai (Childs et al., 2018) savo tyrimuose pastebejo, kad kuo didesnis skausmas, tuo didesnè asmens funkcinè negalia, blogesnė gyvenimo kokybė ir suprastėjusi psichologinė būklè. Tyrejjai (Ulug et al., 2016) vertino moterų, kurios skundèsi lètiniu kaklo skausmu, funkcinę būklę. Tiriamosios buvo suskirstytos ị tris grupes, kurioms taike jègos, ištvermès ir atpa- 
laidavimo pratimų treniruotes. Intervencija truko metus laiko ir rezultatai parodè, kad visos taikytos treniruotès reikšmingai pagerino tiriamujų funkcinę būklę bei gyvenimo kokybę. Autoriai taip pat nurodo, kad didesni pokyčiai nustatyti grupèse, kurios atliko ištvermès ir atpalaidavimo pratimų treniruotes.

Mūsų tyrimo metu, vertinant miego kokybę, tiek tiriamujų, kuriems taikytas kineziterapinis pleistras, tiek tiriamujų, kuriems masažas buvo derinamas su fiziniais pratimais, miego kokybė pagerejjo. Tyrèjas (Eubanks, 2015) savo tyrimo metu analizavo masažo poveikị miego kokybei. Autorius pastebejjo, kad dešimties masažų kursas pagerino miego kokybę, leido pailsèti ir pasinerti i giliausias miego stadijas. Kiti autoriai nagrinėjo elektromiografinius pokyčius miegant ir atliekant masažą, todèl teigia, kad masažas aktyvavo smegenyse vadinamąsias alfa bangas, kurios susidaro medituojant, masažo metu ir negiliose miego stadijose. Alfa bangas generuoja sveiko žmogaus organizmas. Mokslininkai (Fanavoll et al., 2016) tyrė miego kokybę esant kaklo skausmams ir nustatė, kad miego kokybe statistiškai reikšmingai pagerèjo, ir tiriamieji jautėsi labiau pailseję po statinių ir dinaminių kaklo ir pečių lanko pratimų kurso.

Nustateme, kad visų tiriamujų, kuriems buvo taikyta kineziterapija arba kineziterapinis pleistras, bendras nuovargis sumažejo. Mokslininkai (Sherman et al., 2014) tyrė sportininkų nuovargio rodiklių (širdies susitraukimų dažnio, laktato kiekio kraujyje) pokytị masažo metu. Nors ir nenustatyti reikšmingi fiziologinių nuovargio rodiklių skirtumai, sportininkai teigè, kad masažas pagerino atsigavimą po treniruočiu ir kad tai yra tinkama priemonè nuovargiui mažinti. Kaip nurodo mokslininkai (Carlesso et al., 2015), emociniai sutrikimai dažniausiai būna kaip lètinio skausmo pasekmè, o ne priežastis. Todèl skausmo intensyvumas gali turèti itakos emocijų sutrikimams ir nuovargio atsiradimui.

Apibendrinant galima teigti, kad kineziterapijos metodikos yra labai svarbus veiksnys norint pagerinti asmenų, jaučiančių kaklinės stuburo dalies skausmą, gyvenimo kokybę.

\section{IŠVADOS}

1. Tiriamųų, kuriems taikytas masažas, paskui - gydomieji pratimai, gyvenimo kokybė reikšmingai pagerèjo.

2. Tiriamujų, kuriems taikyti gydomieji pratimai, paskui masažas, gyvenimo kokybè taip pat reikšmingai pagerèjo.

3. Tiriamujų, kuriems taikytas kineziterapinis pleistras, gyvenimo kokybė reikšmingai pagerèjo. 


\section{LITERATŪRA}

Baecke, J. A., Burema, J., Frijters, J. E. (1982). A short questionnaire for the measurement of habitual physical activity in epidemiological studies. The American Journal of Clinical Nutrition, 36 (5), 936-942.

Blozik, E., Laptinskaya, D., Herrmann-Lingen, C. et al. (2009). Depression and anxiety as major determinants of neck pain: A cross-sectional study in general practice. BMC Musculoskeletal Disorders, 10 (1), 13.

Buysse, D. J., Reynolds III, C. F., Monk, T. H., Berman, S. R., Kupfer, D. J. (1989). The Pittsburgh Sleep Quality Index: A new instrument for psychiatric practice and research. Psychiatry Research, 28 (2), 193-213.

Cagnie, B., Danneels, L., Van Tiggelen, D., De Loose, V., Cambier, D. (2017). Individual and work related risk factors for neck pain among office workers: A cross sectional study. European Spine Journal, 16 (5), 679-686.

Carlesso, L. C., Gross, A. R., MacDermid, J. C., Walton, D. M., Santaguida, P. L. (2015). Pharmacological, psychological, and patient education interventions for patients with neck pain: Results of an international survey. Journal of Back and Musculoskeletal Rehabilitation, 28 (3), 561-573. doi: 10.3233/BMR-140556.

Cheung, J., Kajaks, T., MacDermid, J. C. (2013). The relationship between neck pain and physical activity. The Open Orthopaedics Journal, (Suppl. 4), 7, 521.

Childs, J. D., Cleland, J. A., Elliott, J. M. et al. (2018). Neck pain: Clinical practice guidelines linked to the International Classification of Functioning, Disability, and Health from the Orthopaedic Section of the American Physical Therapy Association. Journal of Orthopaedic \& Sports Physical Therapy, 38 (9), A1A34.

Costello, M. (2018). Treatment of a patient with cervical radiculopathy using thoracic spine thrust manipulation, soft tissue mobilization, and exercise. Journal of Manual \& Manipulative Therapy, 16 (3), 129-135.

Dawood, R. S., Kattabei, O. M., Nasef, S. A., Battarjee, K. A., Abdelraouf, O. R. (2013). Effectiveness of kinesio taping versus cervical traction on mechanical neck dysfunction. International Journal of Therapies and Rehabilitation Research, 2 (2), 1.

Delgado, E. V., Romero, J. C., Escoda, C. G. (2010). Myofascial pain associated to trigger points: a literature review. Part 2: Differential diagnosis and treatment. Medicina Oral, Patología Oral Y Cirugía Bucal. Ed. Inglesa, 15 (4), 19.

Eubanks, J. D. (2015). Cervical radiculopathy: Nonoperative management of neck pain and radicular symptoms. American Family Physician, 81 (1), 33-40.

Fanavoll, R., Nilsen, T. I., Holtermann, A., Mork, P. J. (2016). Psychosocial work stress, leisure time physical exercise and the risk of chronic pain in the neck/shoulders: Longitudinal data from the Norwegian HUNT Study. International Journal of Occupational Medicine and Environmental Health, 29 (4), 585-595.

Konin, J. G. (2006). Special Tests for Orthopedic Examination. Slack Incorporated.

Lee, M. H., Park, S. J., Kim, J. S. (2013). Effects of neck exercise on high-school students' neck-shoulder posture. Journal of Physical Therapy Science, 25 (5), 571-574.

Liu, R., Kurihara, C., Tsai, H. T. et al. (2017). Classification and treatment of chronic neck pain: A longitudinal cohort study. Regional Anesthesia and Pain Medicine, 42 (1), 52-61.

Pasero, C. (1999). Pain: Clinical manual. Mosby Incorporated.

Sherman, K. J., Cook, A. J., Wellman, R. D. et al. (2014). Five-week outcomes from a dosing trial of therapeutic massage for chronic neck pain. The Annals of Family Medicine, 12 (2), 112-120.

Stankus, A. (2007). Multidimensional fatigue inventory. Biol Psychiatr Psychopharmacol, 9, 86-87.

Uluğ, N., Yakut, Y., Alemdaroğlu, İ., Yılmaz, Ö. (2016). Comparison of pain, kinesiophobia and quality of life in patients with low back and neck pain. Journal of Physical Therapy Science, 28(2), 665-670.

Varoneckas, G. (2003). Subjektyvus miego ịvertinimas pagal Pitsburgo miego kokybès indeksą. Nervu ir psichikos ligos, 4 (12), 31-33.

Vernon, H., Mior, S. (1991). The Neck Disability Index: A study of reliability and validity. Journal of Manipulative and Physiological Therapeutics, 14 (7), 409-415. 


\section{EFFICIENCY OF THREE DIFFERENT PHYSIOTHERAPY PROGRAMS FOR IMPROVING THE QUALITY OF LIVE IN INDIVIDUALS WITH CERVICAL SPINE PAIN}

\section{Evelina Ašmontaitė, Vilma Dudonienè}

Lithuanian Sports University

\section{ABSTRACT}

Background. Neck pain is a global health disorder that greatly affects a person's quality of life. Due to differently assessed methodologies, there is a lack of unanimous opinion among researchers which physiotherapy methodology is the most effective in reducing cervical spine pain, so we have chosen to compare three different physiotherapy programs.

The aim of the study is to analyse the impact of different physiotherapy programs on the quality of life of individuals with neck pain.

Methodology of the research. The study included 55 subjects who complained of non-specific chronic neck pain. The subjects were divided into four groups: the first $(\mathrm{n}=15)$, who were initially subjected to neck and shoulder massage, followed by neck and shoulder stretching and strengthening exercises (massage and exercises), the second $(\mathrm{n}=15)$ - to the application of the neck and shoulder stretching and strengthening exercises followed by neck and shoulder massage (exercises and massage), the third ( $\mathrm{n}=13)$ - only to kinesiological taping (KIN taping), and the fourth $(\mathrm{n}=12)$ - control group with no physiotherapy intervention. Before and after the interventions, the quality of life of the subjects was assessed with the index of neck disability (NDI), the quality of sleep (the Pittsburgh sleep quality index), and fatigue was also evaluated.

Results. Compared to the control group, all groups had statistically significant decreased mean of neck disability index (NDI), fatigue, and improved sleep quality.

Conclusions. 1. Subjects who had neck and shoulder massage first followed by neck and shoulder stretching and strengthening exercises, had a statistically significant improvement in their quality of life. 2. Subjects who had neck and shoulder stretching and strengthening exercises first followed by neck and shoulder massage, significantly improved their quality of life. 3. Subjects who applied only kinesiological taping had a statistically significant improvement in the quality of life.

Keywords: neck pain, massage, kinesiotaping, exercises, quality of life. 